\title{
Suspicion of radiological overexposures in Georgia (1998): The role of IPSN
}

\author{
P. VOISIN*, L. LEBARON-JACOBS*, J.-F. BOTTOLLIER-DEPOIS*, \\ P. GOURMELON*
}

(Manuscript received 27 June 2000, accepted 13 February 2001)

ABSTRACT At the end of July 1998, three ${ }^{137}$ Cs sources (between 0.17 and $150 \mathrm{GBq}$ ) were found in the vicinity of the village of Matkhoji, located at $300 \mathrm{~km}$ to the west of Tbilissi. This site was a former Russian military base, abandoned since 1992 and used now as pasture and a playground for the children. The Georgian Environment Ministry requested assistance from IAEA which sent a mission to the site. This established that a predominantly chronic exposure of part of the population of the village has occurred. The IAEA requested technical assistance from IPSN. A mission, made up of 4 people from IPSN and a representative of the IAEA went to the site from 12 to 17 October 1998 . This mission collected information on the circumstances of the exposure and selected a potentially explored cohort of 112 people, in three groups: children of more than five years and adults of less than 50 years attending the site and members of a family who had a source in their cattle shed. An analysis of hematologic parameters was performed on these people and 85 blood samples were taken for biological dosimetry. The hematologic analysis carried out on the spot did not show any particular anomaly. The biological dosimetry by scoring of unstable chromosome aberrations (dicentric, rings centric, fragments) in blood peripheral lymphocytes was performed on blood samples after air transportation to the specialised laboratory (LDBM) of the IPSN Two successive procedures were initiated. The first was a quick phase of triage not very precise but intended to check if some of these people presented obvious signs of irradiation. Only 50 cells per subject were scored. Seven days were needed to complete this phase. Dicentrics were found in three people only indicating a whole-body dose not exceeding $0.5 \mathrm{~Gy}$ on average. This triage was followed of a more complete but longer examination, where chromosome aberrations were scored in 250 cells. Six weeks were necessary to score 22000 cells from the 85 people. In total, 30 dicentries were scored among only 17 Georgian patients. The highest dose to the whole body estimated from a reference calibration curve was 0.3 Gy The majority of these dicentrics was found in the children having played on several occasions in the former military camp. Unfortunately, the information provided by the population was too fragmentary to permit an effective reconstruction of the individual doses.

RÉSUMÉ Suspicion d'accident radiologique en Géorgie (1998) : Le rôle de l'IPSN.

Fin juillet 1998, trois sources de ${ }^{137} \mathrm{Cs}$ (entre 0,17 et $\left.150 \mathrm{GBq}\right)$ ont été retrouvées enfouies dans le sol à proximité et dans le village de Matkhoji, situé à $300 \mathrm{~km}$ à l'ouest de Tbilissi. Elles proviendraient d'une ancienne base militaire russe, abandonnée depuis 1992, et qui sert maintenant de terrain de jeux et de pâturage. Le ministère de l'Environnement géorgien a dès lors demandé assistance auprès de l'AIEA qui s'est rendue sur place. Il est ressorti de ces investigations qu'une exposition

* Instilut de protection et de sûreté nucléaire, DPHD, IPSN, BP 6, 92265 Fontenay-aux-Roses Cedex, Francc. 
chronique d'une partie de la population du village n'était pas à exclure. Ainsi, l'AIEA a demandé l'assistance de l'IPSN. Une mission, constituée de 4 personnes de I'IPSN et d'un représentant de I'AIEA, s'est rendue sur place du 12 au 17 octobre 1998. Cette mission a permis de recueillir des informations sur les circonstances de l'exposition, de réaliser des prélèvements sanguins auprès de la population concernée pour une analyse sur place de certains paramètres hématologiques et de ramener des échantillons sanguins en vue d'une dosimétrie biologique. À partir de l'enquête réalisée, trois groupes «critiques» ont été déterminés : enfants de plus de cinq ans, adultes de moins de 50 ans fréquentant le site, membres de la famille qui possédaient une source dans leur étable. L'analyse hématologique effectuée sur place (numération - formule sanguine) n'a montré aucune anomalie particulière. Dès le retour de la mission en France, les échantillons sanguins provenant de 85 personnes sélectionnées à partir des trois groupes critiques ont été transportés au Laboratoire de dosimétrie biologique multiparamétrique (LDBM) de l'IPSN. Ces échantillons ont été immédiatement traités afin de pouvoir dénombrer les aberrations chromosomiques instables (dicentriques, anneaux centriques, fragments) potentiellement induites par les rayonnements ionisants dans les lymphocytes sanguins. Deux procédures expérimentales successives ont été initiées. La première est une phase de tri rapide mais peu précise destinée à vérifier si une ou plusieurs de ces personnes présentait des signes évidents d'irradiation. Seulement $\mathbf{5 0}$ cellules sont observées par personne. Sept jours ont permis d'achever cette phase. Des dicentriques ont été mis en évidence chez trois personnes seulement pour une dose globale n'excédant pas $0,5 \mathrm{~Gy}$ en moyenne. Cette phase de tri a été suivie d'une procédure d'expertise plus complète mais plus Iongue, puisque les dicentriques sont recherchés dans 250 cellules par prélèvement sanguin. Six semaines ont été nécessaires pour observer au total 22000 cellules chez les 85 personnes. Finalement, 30 dicentriques ont été dénombrés chez seulement 17 patients géorgiens. La dose la plus forte au corps entier estimée à partir de la courbe de référence du laboratoire était de $0,3 \mathrm{~Gy}$. Une majorité de ces dicentriques a été trouvée chez les enfants ayant joué à plusieurs reprises sur le terrain où se trouvaient les sources radioactives. Malheureusement, les informations fournies par la population sont trop fragmentaires pour permettre une reconstitution efficace des doses reçues.

\section{Background}

Since an accident that occurred in 1997 at Lilo (Georgia) in a border guard training camp, the Georgian authorities, in accordance with the recommendations and with the assistance of the IAEA, set up a radiological protection programme to detect other sources of radioactivity abandoned in former Russian military bases, of which there are an estimated 350 . On the basis of the information received by the IAEA, more than ten locations have been explored, and some sixty sources detected.

In late July 1998 , three ${ }^{137} \mathrm{Cs}$ sources were found buried in the ground close to and in the village of Matkhoji, located $300 \mathrm{~km}$ west of the capital, Tbilissi. The Georgian Environment Ministry then sought assistance from the IAEA, which made two visits to assess the situation and to make the sources safe on a temporary basis. During these investigations, it was discovered that part of the population of Matkhoji village was potentially subjected to chronic exposure. Furthermore, 
some information obtained by the IAEA concerning haematological examination of the population indicate some twenty people with abnormalities in the blood composition that could have resulted from exposure to ionising radiation. In September, the IAEA sought the IPSN's assistance for carrying out exploratory biological dosimetry of the population. A team consisting of four members of the IPSN, as well as a representative of the IAEA, visited Matkhoji from 12 to 17 October 1998 .

The main aims of the mission were:

- to directly collect information about the circumstances of accidental radiological exposure at the village of Matkhoji from the Georgian authorities and the villagers concerned;

- to analyse blood samples taken from the resident population, to detect any recent irradiation of a level able to cause an acute irradiation syndrome (haematological syndrome);

- to take blood samples from some tens of people to seek radiation-induced chromosome abnormalities with a view to subsequent biological dosimetry.

\section{Brief mission report}

After travelling to the village of Matkhoji where it was welcomed by the authorities, the team visited the abandoned military site where the sources had been found and are still currently being stored. The conditions of storage were checked: the dose rate at the surface of the protective containment was approximately 10 microSievert per hour. This does not necessarily represent a risk for the population but the conditions of storage are still insecure, without surveillance and do not meet international standards.

Initially, the source of the strongest estimated activity $(150 \mathrm{GBq})$ was found in a pit in the military area. The dose rate at the ground surface level was $1 \mathrm{~Sv} \mathrm{~h}^{-1}$. The second one with an estimated activity of $3.3 \mathrm{GBq}$, was found in an empty yard 4 meters away from the main road and $1 \mathrm{~km}$ from the nearest Matkhoji houses. The third one, with an estimated activity of $0.17 \mathrm{GBq}$, was found in a barn. In this place, the housewife milked the cows two times per day. It was later discovered that one of her children had brought the source from the military base and left in this barn.

The locations of the sources (two outside the village and one in a barn adjoining a house) made it possible to establish the part of the village closest to the site where the population needed to be questioned on their everyday habits in order to determine the critical group to undergo dosimetric exploration. 
A brief survey, intended to assess the state of health and determine the everyday habits of the individuals was carried out on the families living within a $1 \mathrm{~km}$ radius. At the same time, a topographical survey of the area was made by GPS, identifying and locating each house relative to the sources. The survey revealed that information received by the IAEA stating that children had been swimming in a natural pool containing the source of strongest activity was baseless.

Analysis of certain haematological parameters was carried using a haematology monitor brought in by the IPSN and installed in less than ideal circumstances. Meanwhile, the blood samples necessary for subsequent cytogenetic dosimetry analyses were taken.

A "dosimetry critical group" was defined according to two criteria, the distance from the family house to the former military base and the everyday habits (frequency of the visits of the site). In practice, children most frequently went to the site.

The critical group included three sub-groups:

- children living in the village, more than 5 years old, able to go to the site alone;

- members of the family who had the source in their barn;

- adults up to 50 years old, who frequented the site.

The critical group consisted of 85 people and blood samples were taken in two Vacutainer tubes $(5 \mathrm{ml})$ containing lithium heparin. The samples were brought back to the IPSN Laboratory of Multiparametric and Biological Dosimetry under the best possible conditions in view of the state of the Georgian roads, but it cannot be assumed that the transport conditions had no effect on the quality of the results.

\section{Haematological survey of the population}

The haematological survey was carried out on the "dosimetry critical group" ( 85 persons) and on an additional 28 adult persons due to psychological reasons (marked anxiety of the population).

Blood samples from the 113 people were taken into EDTA (anticoagulant) Vacutainer tubes. Blood cell counts were made with a haematological counter analyser (MS 9-Vet., Melet Schloesing Laboratories). This device had been calibrated before the mission with high, normal and low reference blood samples.

The results did not show any haematological abnormalities likely to be related to any recent acute or chronic irradiation syndrome. The results of these blood tests were given to the inhabitants. Three of the patients belonged to the Georgian list 


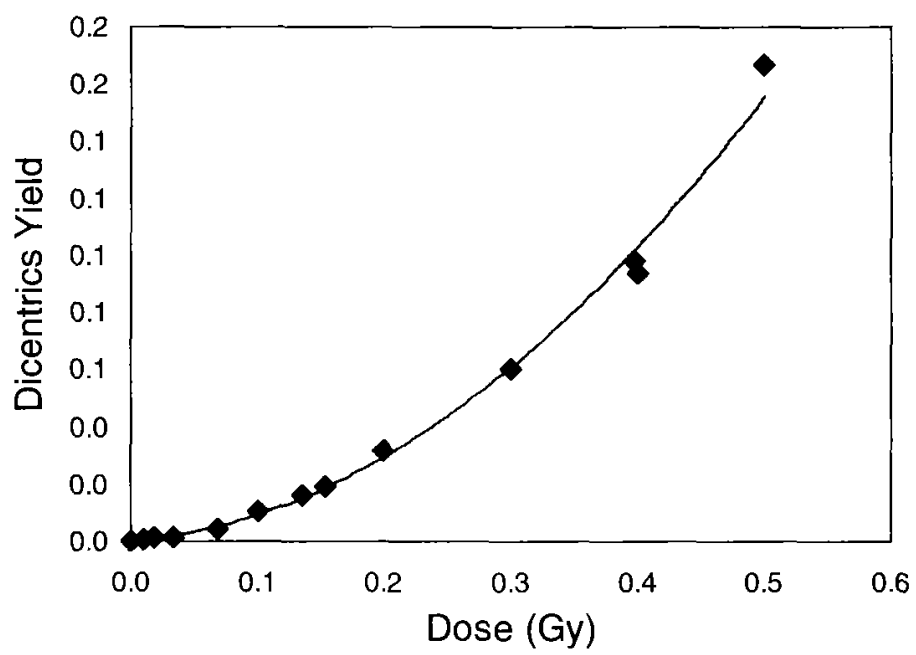

Figure 1 - Reference curve of the laboratory used in biological dosimetry by conventional cytogenetics (dicentrics) and obtained by in vitro acutely irradiating blood samples with $\gamma$-rays from a ${ }^{60} \mathrm{Co}$ source at a dose rate of $0.5 \mathrm{~Gy} \mathrm{~min}^{-1}$.

Courbe de référence utilisée par le laboratoire en dosimétrie biologique par cytogénétique (dicentriques) et obtenue en irradiant in vitro des échantillons sanguins par le rayonnement $\gamma d{ }^{60} \mathrm{Co}$ à un débit de dose de $0,5 \mathrm{~Gy} \mathrm{~min}^{-1}$.

of patients who had been reported to be exhibiting haematological disorders. These patients did not show any radiation related haematological modifications. The team noted a strong desire of the population to undergo these examinations, in both very young children and the aged. This is indicative of the psychological stress of the population confronted with the risk of radiological exposure.

\section{Biological dosimetry survey}

\subsection{Introduction}

The analyses are currently based on the scoring in peripheral lymphocytes, of unstable chromosome aberrations (dicentrics + centric rings), formed by the ionizing radiation. The cells are observed during their mitotic phase, at the metaphase stage. The dicentrics frequency per metaphase is then reported to an equivalent dose to the whole body (IAEA, 1986). To ensure this cytogenetic dosimetry, the laboratory establishes dose-effect relationship for various qualities of radiation and dose rates. These curves are obtained from the aberration scoring in lymphocytes coming from blood samples irradiated in vitro with known radiation doses. The reference curve shown in Figure 1 was obtained by in vitro 
acutely irradiating blood samples with $\gamma$-rays from a ${ }^{60} \mathrm{Co}$ source at a $0.5 \mathrm{~Gy} \mathrm{~min}^{-1}$ dose rate.

This chromosome damage, even after a high irradiation, is still a rare event. For a homogeneous irradiation, the distribution of the damage follows a Poisson statistics. From this it is possible to calculate the uncertainties of the dose assessment which is a function of the number of chromosome aberrations counted and of the number of metaphases scored. The degree of accuracy of the dose and its uncertainty depends on the purpose of the examination.

In the situation of a suspected irradiation involving only a few people and considering the known (or unknown!) circumstances of the radiological accident, the quality of the preparations and the precision of the estimate are privileged. Many hundreds of metaphases may be scored so that the confidence interval is satisfactory. It is a long and tiresome job, requiring several working days for skilled observers.

In the event of an accident involving exposure of a large population, uncertainties in physical dosimetry or clinical symptoms increase in proportion of the number of potentially irradiated individuals. Biological dosimetry is practically useful if each dose estimates can be supplied in the hours following the real or suspected irradiation. The measuring accuracy and the quality of the preparations appear in proportion less important than the deadline. A particular procedure making it possible to combine these various factors was developed and checked during simulation training. The metaphase preparation and chromosome analysis techniques were simplified, and the number of observed metaphases reduced.

\subsection{Methods}

For each people, $10 \mathrm{ml}$ of whole blood was taken by venous puncture into Vacutainer $^{\left({ }^{(}\right)}$tubes with lithium heparin as anticoagulant. Whole blood cultures are set up according to a procedure similar to this recommended by the IAEA report (IAEA, 1986) and published elsewhere (Voisin et al., 1997). Briefly, a blood aliquot is cultured in RPMI 1640 medium, to which is added a mitogenic agent, phytohemagglutinin (Life Technologies), several antibiotics and $10 \%$ foetal calf serum (SVF, Life Technologies). The cultures are set up in duplicate, in addition, on following day in case of contamination problems, bad handling or poor culture rates.

For conventional cytogenetics, it is important to examine only metaphases in first mitosis, because $50 \%$ of the cells carrying "unstable" chromosome 
aberrations are expected to be eliminated during each mitosis. The observation of second mitosis or later would lead to an underestimation of the dose. For this purpose, a thymidine analogue, 5-Bromodeoxyuridin (Sigma), is added to each culture (Perry and Wolf, 1974).

After 46 hours of culture at $37^{\circ} \mathrm{C}$, a mitotic inhibitor, demecolcin (Life Technologies), is added, and the culture prolonged for a further 2 to 3 hours. The lymphocytes are harvested by centrifugation, and a $\mathrm{KCl}$ hypotonic shock $(0.075 \mathrm{M})$ is applied to lyse red blood cells and to inflate lymphocytes nuclei. After centrifugation, the cells are fixed by addition of methanol/acetic acid mixture $(3 / 1, v / v)$. The metaphases are spread out by projection over clean and wet microscope slides and visualized by FPG technique (Perry and Wolf, 1974).

A quick observation, under phase contrast illumination, of the first culture slides makes it possible to identify the samples with too few mitotic cells: the additional duplicate culture can then be prolonged by a few hours.

After staining with Giemsa (Life Technologies), the metaphases are examined under bright field microscopy and all unstable chromosome aberrations (dicentrics, centric rings and acentrics) scored. Only the dicentrics and centric rings, being really specific for the ionizing radiations, are used for the estimation of a dose. Indeed, the spontaneous rate of dicentrics in the normal population, according to our experimental conditions, is lower than 1 per 1500 metaphases. It is ten times lower for the centric rings. So that the confidence interval is satisfactory (at least equal to $0.2 \mathrm{~Gy}$ ), a minimum scoring of 100 dicentrics is required or, if this number cannot be reached, 500 metaphases at least are observed (Fig. 2).

In order to address the problem meeting a deadline in the case of triage on a great number of potentially irradiated individuals, a simplified cytogenetics technique is applied (Tab. I). Briefly, the modifications of the technique described above apply to: an increase of the technicians involved in the preparation and analysis of the samples; a reduction of the number of cultures simultaneously set up; the observation of only 50 metaphases enough to ensure a confidence interval of $1 \mathrm{~Gy}$. In the critical dose range from 1 to $2 \mathrm{~Gy}$, corresponding to the appearance of the acute radiation syndrome, a confidence interval of \pm 1 Gy seems satisfactory for the hospital team in charge of the individuals exposed to ionizing radiation.

\subsection{Results and discussion}

Considering the large number of blood samples to process and because we were unable to select the individuals on likelihood of serious overexposure, based on 


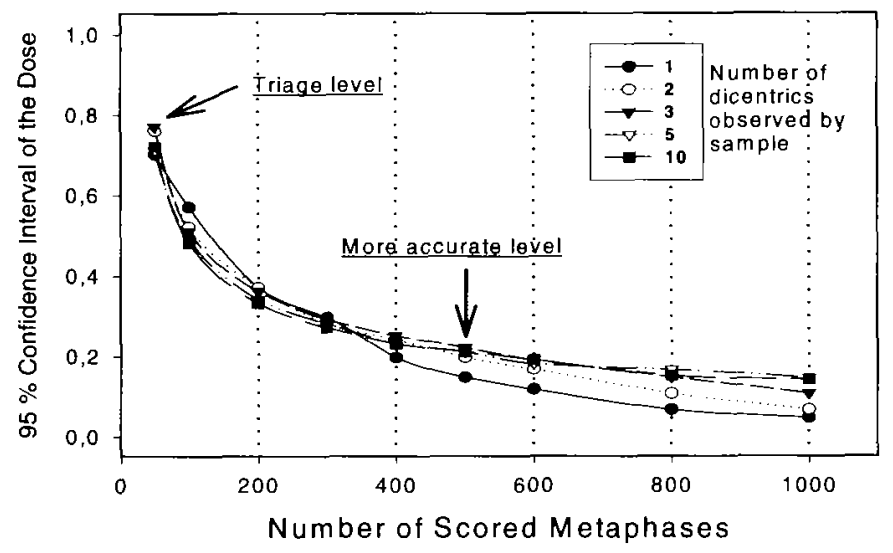

Figure 2 - Upper limit of the $95 \%$ confidence interval of the dose estimate, according to the number of lymphocytes observed and calculated for ${ }^{60} \mathrm{Co} \gamma$-rays by using the dose-effect relationship $Y=0.004+0.0374 D+0.0549 D^{2}$ (with $Y=$ dicentrics yield and $D=$ dose in Gy from the $\gamma$-rays of ${ }^{60} \mathrm{Co}, 0.5 \mathrm{~Gy} \mathrm{~min}^{-1}$ dose rate). The dicentrics are assumed to follow a Poisson distribution. The low influence of the number of dicentrics on the confidence limits is to be noted.

Limite supérieure de l'intervalle de confiance à $95 \%$ de la dose estimée, en fonction du nombre de lymphocytes observés et en utilisant la courbe de référence $Y=0,004+0,0374 \mathrm{D}+0,0549 \mathrm{D}^{2}$ où $D$ est la dose reque par le rayonnement $\gamma d u{ }^{60} \mathrm{Co}$ à $0,5 \mathrm{~Gy} \mathrm{~min}^{-1}$ et $Y$ la fréquence de dicentriques observés. La répartition des dicentriques est supposée suivre une distribution de Poisson. On notera le peu d'influence relatif du nombre de dicentriques sur la valeur de l'intervalle de confiance.

their hematological data, we have performed this dose assessment in two phases: a first quick triage followed by a more precise assessment.

\subsubsection{Triage phase}

The chromosome aberrations were scored only in first complete metaphases, i.e. having 46 centromeres, others being rejected after checking. The total number of metaphases observed was thus higher than the necessary number of $85 \times 50$ i.e. 4250 cells. The maximum number of 200 metaphases per day analyzed by each of the six operators was consistent with the rate that has been previously achieved in the emergency exercises.

On the 85 analyzed blood samples, dicentrics were found in three samples only:

- a sample had two cells carrying one dicentrics each;

- a sample had a cell carrying one dicentrics;

- a sample had a cell carrying two dicentrics. 


\section{TABLE I}

Main methodological differences in the preparation of the blood samples for biological dosimetry by conventional cytogenetics, depending on the level of accuracy required.

Principales différences méthodologiques dans la préparation et l'analyse des échantillons sanguins pour la dosimétrie biologique par cytogénétique conventionnelle, selon la finalité de l'examen, expertise ou tri.

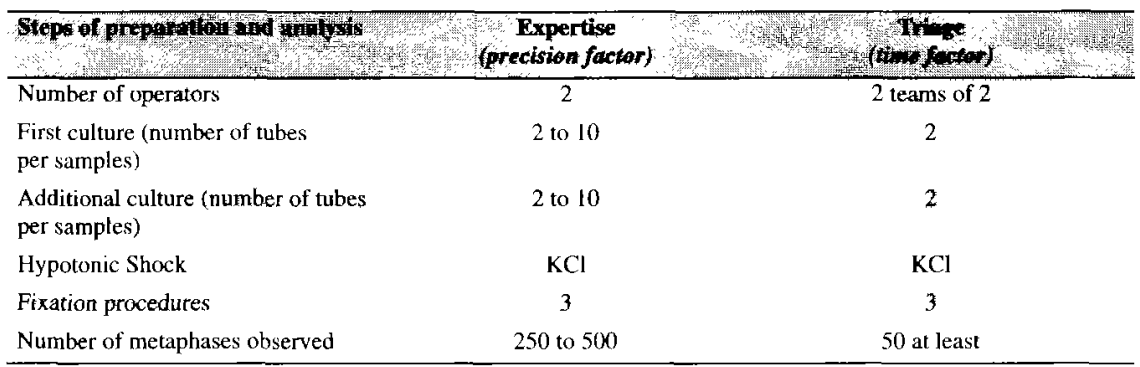

Two dicentrics observed in 50 cells suggests whole body irradiation of about $0.5 \mathrm{~Gy}$ but with a wide confidence interval so that it is not possible to derive a really accurate dose. However, the purpose of the method used here was triage, i.e. a coarse separation in to a few categories, namely: "little or not irradiated, moderately irradiated and strongly irradiated".

\subsubsection{Expertise phase}

Based on the same endpoint, namely scoring of unstable chromosomal aberrations, the purpose of this second step was to improve the statistical precision by increasing the number of lymphocytes observed. The objective was to score 250 metaphases per individual. This objective was achieved for all patients but two. Because of many tasks routinely performed by the laboratory, it was not possible for operators to discharge all their normal activities. Nevertheless, over 22000 cells were scored in only six weeks.

The results are summarized below:

1 - number of people examined: 85 ;

2- number of complete cells examined: 21575 ;

3- number of people presenting dicentrics in any (complete and rogue) cell: 20;

4- number of people presenting dicentrics, only in complete cells: 17;

5- number of dicentrics, in complete cells, for all people: 30 ;

6- number of people presenting "rogue cells": 7.

Among the people presenting chromosome aberrations in complete cells, the number of dicentrics found was never higher than 3. This is shown in Figure 3, 


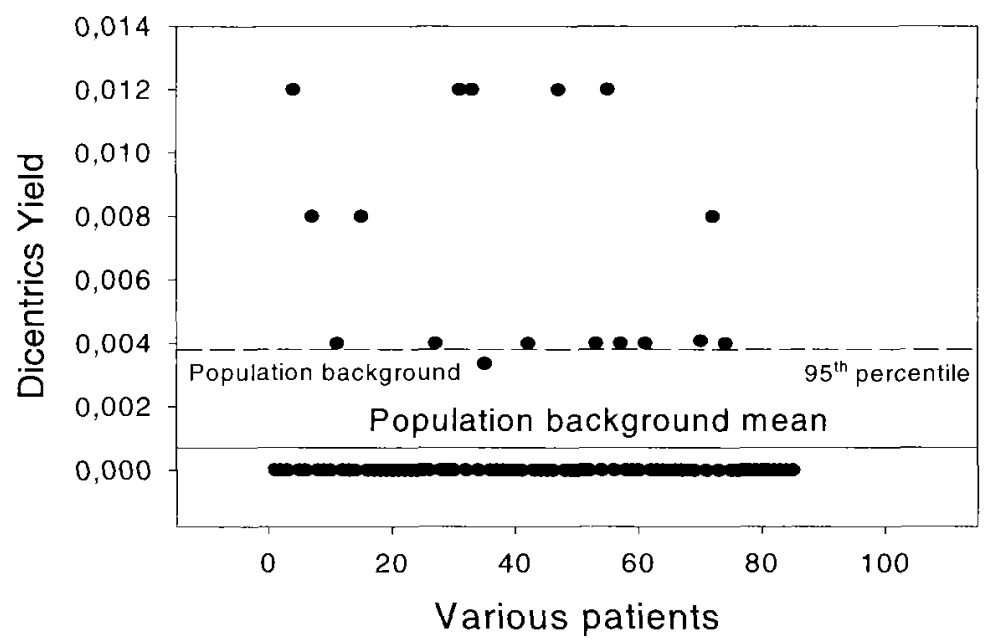

Figure 3 - Dicentrics yield observed in the 85 Georgian potentially exposed individuals. For comparison purpose, the spontaneous dicentrics frequency in a normal Western Europe population is represented by two lines, the population background mean (solid) and the 95th upper percentile (dotted).

Fréquence de dicentriques observée chez les 85 personnes géorgiennes potentiellement exposées. À titre de comparaison, la production spontanée de dicentriques dans une population occidentale est représentée par sa moyenne (trait plein) et par la limite supérieure de son intervalle de confiance à $95 \%$ (trait pointillé).

which summarizes the dicentrics yields observed in the 85 subjects. This is in agreement with the normal haematological data obtained on the spot by the IAEA/IPSN mission at Matkhoji. The spontaneous dicentrics frequency in a normal Western Europe population is about I dicentric per 1500 cells, according to the laboratory data, and is represented in Figure 3 by two lines, the population background mean (solid) and the 95th upper percentile (dotted). It can be pointed out that 16 individuals (and especially 8 of them) out of the 85 Georgian people presented a higher number of dicentrics than expected. One dicentric in 250 observed metaphases was scored in 9 individuals.

By reference to the laboratory's control data base one would expect to have observed in the 21575 lymphocytes scored from these 85 people, 14 "spontaneous" dicentrics. The total number of dicentrics observed in the studied Georgian cohort appears significantly higher (chi-square test, $p<0.01$ ). Finally, a tricentric could be noted in observed lymphocytes of one individual for whom the dose is highest. Even if it is not possible to definitively prove a real overexposure for most individuals, all these data viewed overall suggest a collective exposure to ionizing radiation. 
Our results are given only in dicentrics yields. By reference to the calibration curve established by in vitro acutely irradiating blood samples with ${ }^{60} \mathrm{Co} \gamma$-rays, at $0.5 \mathrm{~Gy} \mathrm{~min}^{-1}$, the dose estimate would be $0.3 \mathrm{~Gy}$ for the strongest suspected exposures. However, this value has little significance considering the irradiation circumstances.

Some lymphocytes presenting multiple chromosome damage in the same cell (e.g. 8 dicentrics, 1 centric ring and 13 excess acentrics) were also noted, not compatible with the suspected exposure circumstances. They are described in the scientific literature as "rogue cells". Sevankaev et al. (1993) reported observing 8 rogue cells among more than 63000 lymphocytes in 328 children from Belarus. The origin of these rogue cells is unknown. One hypothesis involves the presence of hot particles containing high LET emitters (neutrons or alpha particles). The appearance of this major chromosomal damage in lymphocytes has been also related to viral infections (Sevankaev et al., 1993). Whatever the reason, the number of rogue cells observed in the 85 Georgians seems particularly high, considering the literature. It could be interesting to study a local control population, in order to verify the background frequencies of dicentrics and rogue cells.

\section{Conclusion}

Faced with inadequate local resources, the mission found it possible:

- to correct some previous information in the IAEA's possession, particularly concerning earlier haematological analyses and the circumstances of exposure of the population;

- to make on-the-spot haematological analyses which were extremely reassuring in excluding any acute or chronic haematological syndromes associated with exposure to ionising radiation;

- to bring back blood samples for biological dosimetry.

Despite bad transporting conditions for the blood samples, biological dosimetry results could be obtained. Confirmation of the exposure of these 8 people would probably be obtained by extending the lymphocyte scoring, although the value of such data in the context of deciding the risk to health of such persons is debatable. However, all people presenting a dicentric in the present assessment should be carefully followed up.

Acknowledgements: We would like to thank Drs Marc Benderitter, Valérie Chambrette, Irène Sorokine-Durm and Mrs Valérie Durand, Martine Delbos, Annie Le Roy and Nathalie Paillole for their valuable assistance in all the steps of the biological dosimetry assessment. 


\section{REFERENCES}

IAEA (International Atomic Energy Agency) (1986) Biological dosimetry: Chromosomal aberration analysis for dose assessment. Technical Report Series n²60 1AEA, Vienna.

Neel J.V., Major E.O., Awa A.A., Glover T., Burgess A., Traub R., Curfman B., Satoh C. (1996) Hypothesis: "rogue cell"-type chromosomal damage in lymphocytes is associated with infection with the JC human polyoma virus and has implications for oncogenesis, Proc. Nat. Acad. Sci. USA 93, 2690-2695.

Perry P., Wolf S. (1974) New Giemsa method for the differential staining of sister chromatids, Nature 251. $156-158$.

Sevankeaev A.V., Tsyb A.F., Lloyd D.C., Zhloba A.A., Moiseenko V.V., Skrjabin A.M., Climov V.M. (1993) "Rogue" cells observed in children exposed to radiation from the Chernobyl accident, Int. J. Radiat. Biol. 63, 361-367.

Voisin P., Lloyd D., Edwards A. (1997) Chromosome aberrations scoring for biological dosimetry in a criticality accident, Radiat. Prot. Dosim. 70, 467-470. 